Journal of English Teaching Adi Buana, Vol. 03 No. 01, April 2018

\title{
DEVELOPING ENGLISH TEACHING MATERIALS FOR YOUNG LEARNERS
}

\author{
Hertiki \\ University of PGRI Adi Buana Surabaya \\ hertiki@unipasby.ac.id
}

\begin{abstract}
Teaching material is needed in teaching-learning activities in the classroom. Without an appropriate material, a teacher might have difficulty in delivering the lesson, especially for children. TEYL (Teaching English to Young Learners) is a compulsory subject for the English Department students of Adi Buana University and this course is only offered for the final year students. To support TEYL course, undergraduates need to create English Teaching Materials that are useful for both teacher and students in school. Therefore, it is important to conduct this study in order to develop English teaching materials that meet the students' need. The author concerns on the authentic teaching materials made by the undergraduates. The final product of English teaching materials for young learners are Let's Count and Clip, Boggle, Noun Clipboard, What Time is It?, and Dominoes Card. All in all, these English teaching materials have been used in one of the private schools (BP school) to help children learn English. Based on the result, it can be concluded that Let's Count and Clip as the most popular material among the children. It is quite attractive and appropriate to help grade three of primary school learn English.
\end{abstract}

Keywords: English materials, young learners, teaching strategy

\section{INTRODUCTION}

Teaching English for Young Learners (TEYL) in Indonesia is not an easy thing to do. Teaching young learners is totally different from teaching adults. Children tend to change mood every minute and they like to move around all the time. On the other hand, kids show a greater motivation than adults. The teachers have to find an interesting strategy to improve the students' skills and to make a good atmosphere in the class. Creating an interesting English class need a good preparation. The process of teaching and learning is one way for the teachers to transfer the information to the students. So, the teachers have to use simple language so that the students can easily understand the material. In some schools in Indonesia, the students are still afraid oflearning English. It can also be difficult to motivate learners. Children may struggle to understand the relevance of learning English as they have little contact with speakers of the language (Ho, 2003; Li, 1998). Thus, teachers have to be inventive in selecting interesting activities and must provide a great variety of them. 
Developing English Teaching Materials especially for young learners is a big challenge for any teachers who teach in primary school. Teachers are expected to be more creative in designing the materials for students and also teachers must be able to teach the materials to students. The goal is to help students develop their English skills. This study offers ideas for classroom activities to support and help students enjoy learning English. In addition, the roles of teachers of young English learners have also contributed to the success of teaching itself in the classroom. This study is conducted to investigate the students' activities of the third gradein BP school (private school) in Surabaya. Their age is between 9 to 10 years old. The students are a mixed ability group who have a very basic level of English. In this school, English is considered as an optional local content subject. Itfocuses on the teaching materials created by undergraduates that use in young learners classroom. The five final product are Let's Count and Clip, Boggle, Noun Clipboard, What Time is It?, and Dominoes Card.The expected outcome of this paper is to find out whether the teaching materials made by undergraduates meet the students' need or not in school.

\section{REVIEW RELATED TO LITERATURE}

\section{How to Teach English to Children}

As mentioned by Verner (2015), the three powerful strategies are:

1. Make it fun

Some teachers believe that children learn best through play. There are some ways that can be done by the teachers to make learning more fun with the students.

- First, play games. Games can be one of the alternatives to make fun learning in the classroom. Games have a goal to accomplish and also help students to compete with their classmates. For example: If the students win a game, they will feel good about the success. The following examples of super fun games for young learners areSimon Says, Mother May I, Memory, Treasure Hunt etc. Young learners usually play games for fun. According to Khan (1996), teachers need to consider which games to use, when to use them, how to link with the textbook, more specifically, different games will benefit students in different ways. The key to a successful language game is that the rules must be clear and the game must be fun.

- Second, be creative. In young learners classroom, teachers must have different plans each day. The students will be bored if the teachers do the same thing in class every day. The point is the teachers must focus on the students' exercises. Also, teaching-learning activities can be done outside the classroom, not only inside the class. In addition, Harmer (2002) stated that games, stories telling and song are activities that are suitable young language learners.

2. Make it active

Montessori (2018) suggested that young learners are not able to learn unless they are also able to move. TPR (Total Physical Response) is a teaching method that works really well with children. Children move as they learn. They follow teachers' instructions and copy the movements. 
3. Don't put pressure on your students

No matter what teachers do in class, try not to pressure the students. There are some ways avoid putting pressure on students such asmodeling correct language use, don't give everything with a grade and also don't correct every error the children make.

\section{Designing English Teaching Materials}

Designing English teaching materials in young learners classroom should be based on how children learn and how they learn the language. There are three stages in designing English teaching materials as suggested by Christie (2003):

1. Preparation in selecting learning materials used for a natural context and a structured context for learning and using language (younger children) and other contexts for encouraging language (older children)

2. Conducting a workshop for a balanced approach to instructions, teaching meaning and skills, and meeting special needs

3. Doing an assessment of determining what young learners know and can do and on-demand assessment.

The learning materials have to be focused on something that children must used the language. In other words, teachers are to expand students' learning and opportunities to use language in the English classroom. To fulfill what students need to promote the language use in English class, teachers can provide authentic materials that are suitable for the students' need. An advantage of introducing authentic materials at an early stage of language learning is to help students become familiar with the target language (Field in Mousavi and Iravani, 2012).

\section{English Teaching Materials for Young Learners Classroom}

\section{Activity 1: Let's Count and Clip}

Strategic focus: Numbers 0-10

Time: 10-15 minutes

Materials: Flashcards, numbers, rope, clip

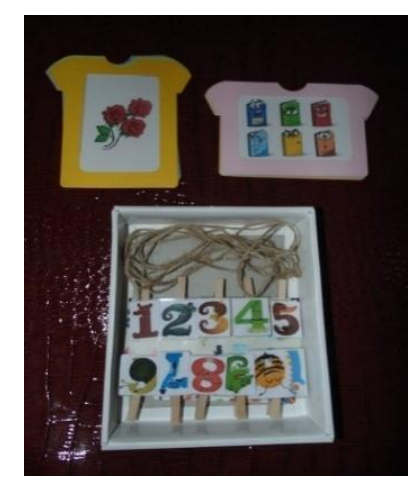

Directions:

1. Show students the media of Let's Count and Clip to attract students' interest.

2. Tell students that you are going to teach numbers.

3. Ask students to sing Little Indians along with you before beginning the lesson. 
4. Hang on the numbers $0-10$ on the whiteboard.

5. Prepare the flash cards and ask the students to count the object on the card and match with the suitable number. After matching, the students must spell and write the number on the whiteboard

6. After the students know how to do the activities, divide the students into two groups.

7. Play the games with the students.

8. Ask students to line up based on the group, then each member of the group come forward to match flash card and number and write the spelling.

9. For those who can match the pictures and the numbers correctly, they get 1 (one) point for each group. The winner can be seen from the total point of two groups.

Activity 2: Boggle Jr.

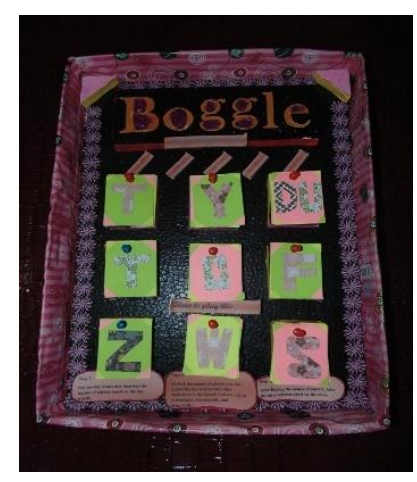

As stated by Hasbro (2005), Boogle Jr. is a word-finding game for two or more players. Boogle encourages players to create as many words in a short time. In other meaning, Boogle is a popular word game for every player.

Strategic focus: word recognition and spelling

Time: $15-20$ minutes

Materials: Boogle Jr. Game tray, 3-letter words, picture-cards

Directions:

1. Point to the picture on the card and ask the students what it is - cat, sun, dog, pen, sea, etc.

2. Point to the word below the picture, say the word, then spell the word aloud, letter by letter, for example: "It's a cat... C-A-T"

3. Divide the students into groups. One group consists of two people.

4. Go back to the first letter, and have the students find that letter on the Boogle tray and directly place under the letter as it appears on the card.

5. Do it again until all the cards have been used.

6. Whoever has finished the first during the round gets one point. 


\section{Activity 3: Noun Clipboard}

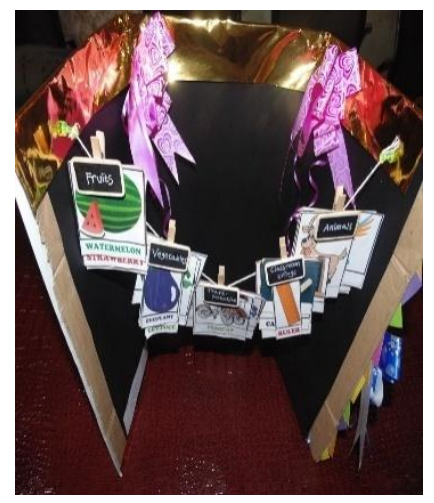

Strategic focus: Fruits, Vegetables, Transportations, Classroom Things, Animals Time: 10-15 minutes

Materials: small cue card with the name of the object and picture

Directions:

1. Show students the book of Noun Clipboard to attract students' interest.

2. Tell students that you are going to review about the noun.

3. Ask students to name kinds of fruits, vegetables, transportation, classroom things, and animals orally.

4. Hang on the theme on the Noun Book Clipboard.

5. Spread all the small cue cards with pictures on the tray.

6. Ask the students take one cue card from the tray.

7. Call the students to come in front of the classroom one by one.

8. Have the child clip the picture based on the suitable theme, for examplewatermelon - Fruits, dog - Animals, eggplant - Vegetables, pedicab Transportation, ruler - Classroom Things.

\section{Activity 4: What Time is It?}

Strategic focus: Time

Time: $15-20$ minutes

Materials: Time Board Games

Directions: (Taken from Daymut, 2009)

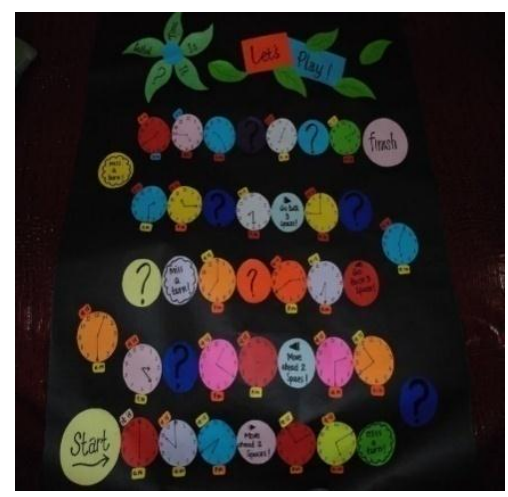


Divide the students into groups consist of 3-4 people.

1. Briefly describe how to play time board games to the students. Introduce the game board. Explain what you have on the board. Identify the start and finish points. Note special spaces like: "Move Ahead 2 Spaces, Miss a Turn, Go Back 3 Spaces" to the students.

2. Introduce the game pieces, for exampledice and tokens. Explain each function of the game pieces. The teacher could say: This is the dice. It has six sides and each side has dots on it. There will be one, two, three, four, five and six dots on a side. Put the dice on your hand and shake it, then drop it on the game board. Look at the dots on the dice and count it. It shows the number of spaces you move on the game board.

3. Practice using the game pieces with the game board. Start playing the game with the prompts questions on the game board. The question will be: What time is it? It is seven o'clock.

\section{Activity 5: Dominoes Card}

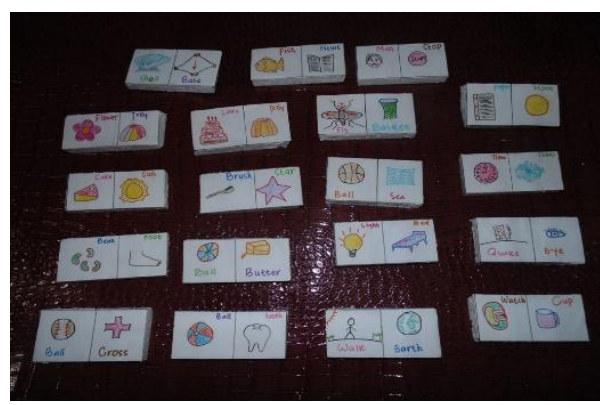

Strategic focus: vocabulary

Time: $10-15$ minutes

Materials: dominoes card

Directions:

1. Put the dominoes card face down on the table and mix them up.

2. Each player takes 6 dominos; for a game with more than 3 players, each player should take 3 dominos.

3. The first player places one of their dominoes face up on the table.

The second player tries to put a domino on the table that matches one side of the dominoes card. For example: On the card, it has the picture of ball and eyes, the next player should match one of the pictures, either ball or eyes.If a player cannot go, the player picks a domino from the pile and skips turn.

4. The winner is the first person to get rid of all their dominoes. But if no one can go out, then the person with has the fewer card left is the winner. 


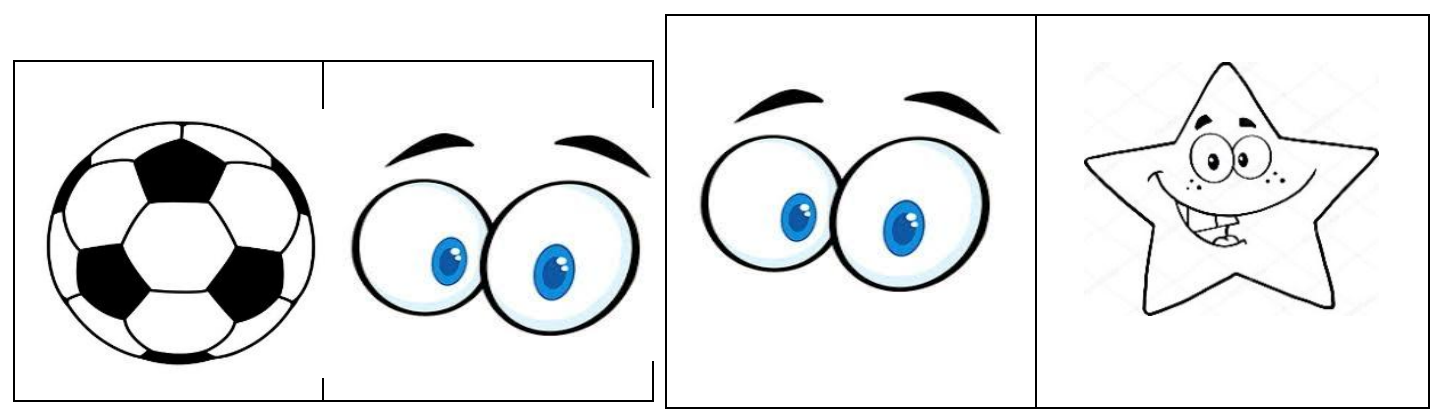

\section{METHOD}

This study is a descriptive study in a survey form because it describes English teaching materials and all the components based on a questionnaire (in this case aSelf-Evaluation form) and interviews. The subjects of the present study were 6 boys and 9 girls - students in BP school.

The instruments were interview questions and observation. To obtain more valid data, an interview with the students were conducted. For the triangulation of the data, the students who have involved in the activities were also asked to fill in the Self-Evaluation form. Besides, they were also interviewed to get more supportive data.

\section{FINDINGS AND DISCUSSION}

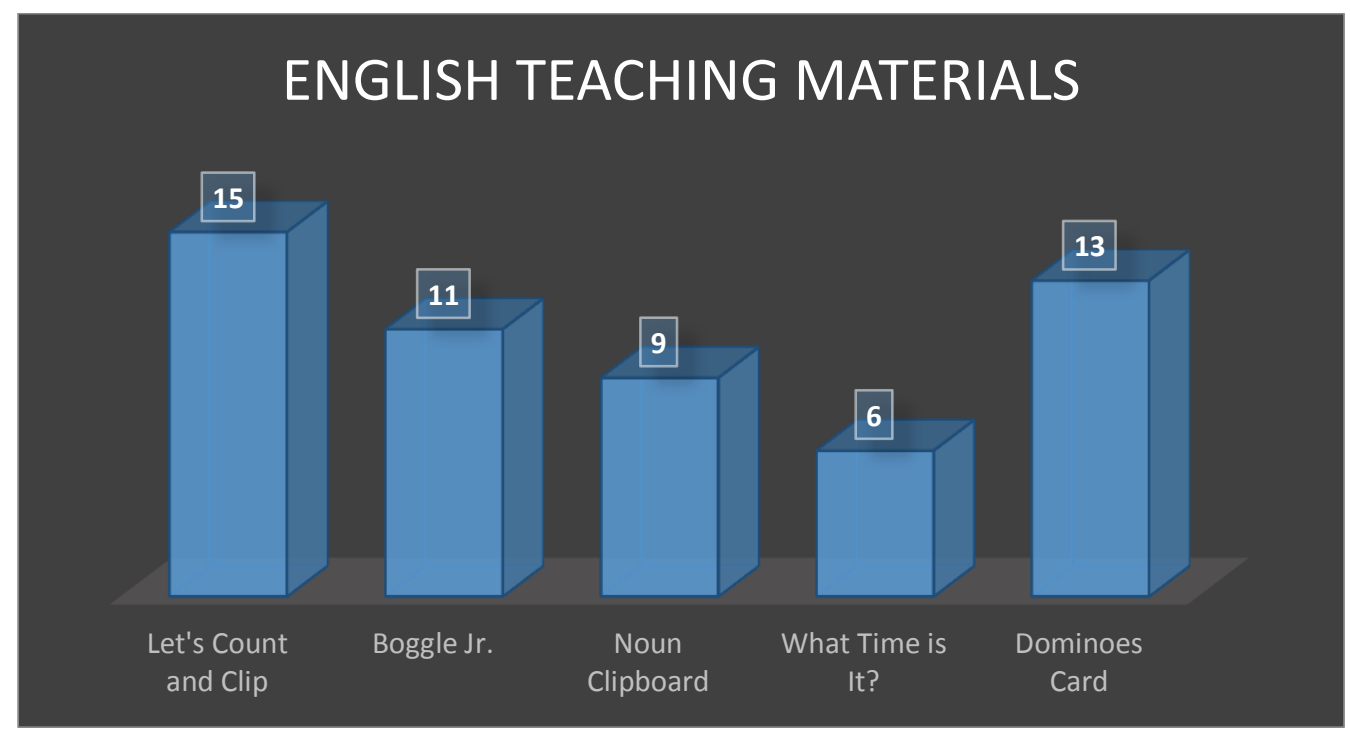

All the activities were conducted in class with 15 students in one of the private schools in Surabaya (BP School). The condition of the classroom was good and big enough with movable chairs. The students also were eager to follow all the activities given by the teacher. After doing the five activities, the teacher handed self-evaluation form to the students in order to know about their feeling in doing those activities.

From the chart above, it can be seen that the highest rank was "Let's Count and Clip" (15 students). All the students chose this activity as the easiest 
activity to be done. They were required to match the numbers $0-10$ with the pictures on the whiteboard. Moreover, the students loved to do activities that asked them to compete among their classmates. During the observation, the students took part in singing the song of "Little Indian". They followed the teacher's instruction exactly the same with the movement. The children also actively participated to match the flash cards and numbers for the material Let's Count and Clip. For this activity, there were 4 children who had difficulty in spelling the numbers. Student A misspelled number 2 (two) - 'too'. Student B wrote 'sick' for number 6 (six). Student $\mathrm{C}$ mentioned 'fife' for number 5 (five). Student D answered 'tree' for number 3 (three).

For "Dominoes Card", there were 13 students chose this activity as the second rank. This activity was done individually and did not require a lot of time to complete. They could play dominoes and practice with their friends without any difficulty at all.From the observation, the students were so happy in doing this activity. One of the reasons was the design of the dominoes card. It filled with pictures and most of the students did not have any difficulty at all.

Next, 11 students picked "Boggle Jr." as the third activities. This activity was a bit tough for the students because only fewer students could do the word recognition and spelling. They were lack of knowledge in making words. Some of the students still had the same difficulty in spelling the words. For example, when the teacher asked group one: What picture is this? This is a cat. Then, the teacher continued the question: How do you spell CAT? Find the letter on the tray now! One group took the wrong letter - KAT instead of CAT. Another example of the word SUN, the students chose the letters SON.

Another activity was chosen by the students was "Noun Clipboard" (9 students). For this activity, the students loved the activity that needed them to move a lot. However, problems occurred because some of the students had low vocabulary mastery. They had difficulty in matching the object with the theme, for example: eggplants with vegetables. The reason was not all students understand the names of the vegetables. In other words, the children were lack of vocabulary knowledge because there were some new vocabularies, such aspedicab, eggplant, dragon fruit, cupboard.

The last activity was "What Time is It?". 6 students chose the activity as the last rank and as the most difficult activity. The students felt difficult when they had to guess the time on the game board such as 07.30, 09.45. However, problems occurred when the students deal with aquarter to..., half past... Besides, the students still put their effort to answer the questions. The children also loved the layout of the board game, especially when they rolled the big dice.

\section{CONCLUSION}

Using various teaching materials in teaching English is not a one-night activity. It needs extra time and several thoughts to create the materials as well. Every student is unique. They have their own preferences. A teacher needs to adjust activities which can maximize the result of the process. The teachers' creativities are a significant factor forstudents' success.

From the findings above, the results showed that the five teaching materials can be used effectively to help young learners to learn English. Furthermore, the use of these five teaching materials has support for the students' 
success. It provides a joyful atmosphere in young learners classroom. The five teaching materials made by the undergraduates also show that the students are interested in the design. Further, it attracts the students at the first sight and they are willing to participate actively in the lesson.

As a result, Let's Count and Clipis the most suitable and popular among the children. It is not only attractive but also appropriate to help grade three of primary school learn English.To speak more broadly, the author would like to give a suggestion for other teachers teaching English to young learners to be more creative and innovative in preparing English teaching materials. The design, layout and general appearance should be considered by the teachers. However, the most important thing is the content and other aspects of English teaching materials before using it. Besides, it is also useful to have a discussion with other colleagues to compare the strengths and weaknesses of each material. For further study, considering that there are kinds of English teaching materials for young learners in the bookstore, it is recommended that other researchers should make studies about an evaluation of English coursebook that used in private and public school.

\section{REFERENCES}

Christie, J. (2003). Teaching Language and Literacy: Preschool Through the Elementary Grades. Boston: Allyn \& Bacon.

Daymut, J. A., (2009). Helpful Strategies for Teaching Children How to Play Board Games. Super Duper Publications. Retrieved on 5th April 2018 from https://www.superduperinc.com

Harmer, J. (2002). The Practice of English Language Teaching. Harlow: Pearson Education Ltd.

Hasbro. (2005). Your Preschooler's First Boggle Game. Retrieved on 2nd April 2018 from https://www.parkerbrothers.com

Ho, W. K. (2003). English Language Teaching in Asia today: An overview. In W. K. Ho \& R. Y. L. Wong (Eds.), English Language Teaching in East Asia Today: Changing Policies and Practices (pp. 1-32). Singapore: Eastern Universities Press.

Khan, J. (1996). Using Games in Teaching English to Young Learners' in (eds)Brumfit, C, Teaching English to Children. From Practice to Principle England: Longman.

Li, D. (1998). "It's Always More Difficult than You Plan and Imagines": Teachers' Perceived Difficulties in Introducing the Communicative Approach in South Korea. TESOL Quarterly, 32, 677-703. doi: $10.2307 / 3588000$.

Montessori, M. (2018). Montessori Education.Retrieved on 6th April 2018 from http://amshq.org

Mousavi, S. A \& Iravani, H. (2012). The Effect of Authentic Versus Non-Authentic Aural Materials on EFL Learners' Listening Comprehension. English Language and Literature Studies Vol 2, No 1; March 2012.

Verner, S. (2015). How to Teach English to Children: 3 Powerful Strategies for Impressive Results. Retrieved on 25th March 2018 from https://www.fluentu.com 
Apppendix 1

SELF-EVALUATION FORM

Name:

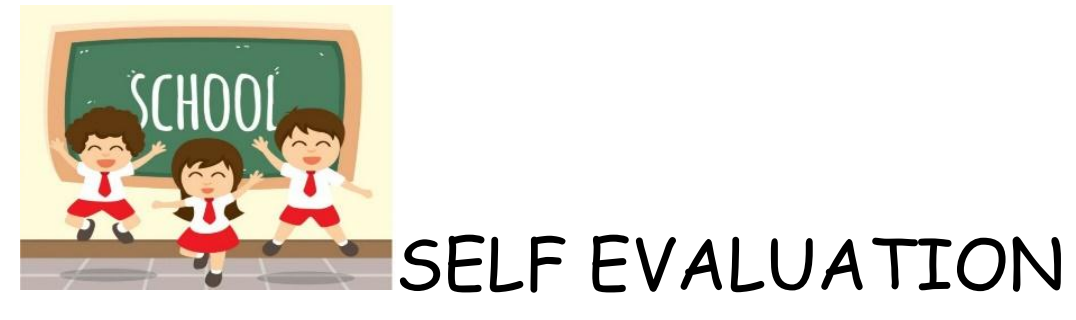

This is how I feel about...

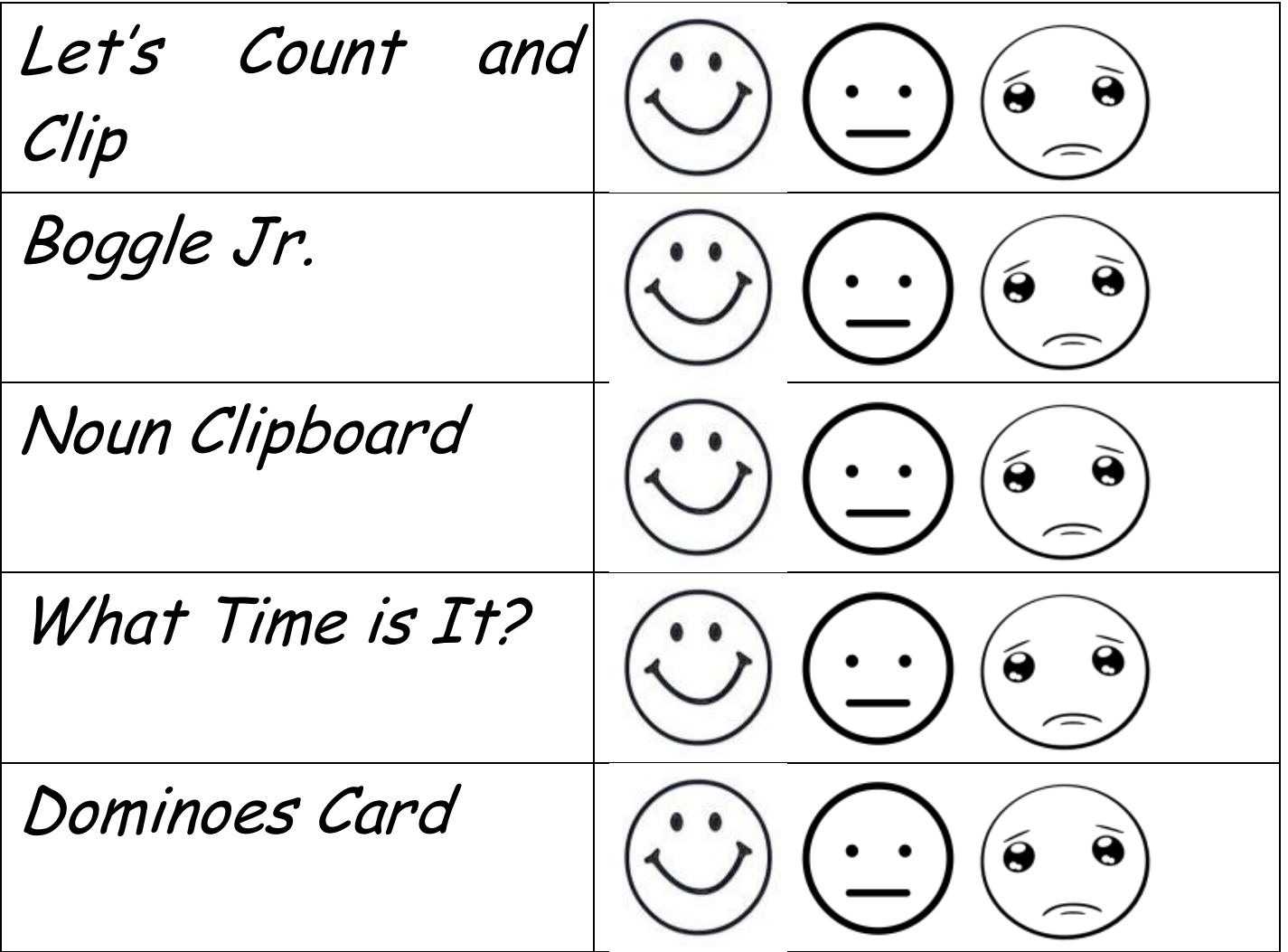




\section{Appendix 2}

\section{Interview Questions (In English and Bahasa Indonesia)}

1. What is your gender? $\square$ Boy $\square$ Girl

2. Do you think you can improve your English by using the activities given by the teacher?

Yes $\square$ No

3. In what ways do the activities help to improve your English skills?

4. Which materialsdid you enjoy most?
a. Let's Count and Clip
b. Boogle Jr.
c. Noun Clipboard
d. What time is it?
e. Dominoes Card

5. Why you like the materials?
a. Colourful pictures
b. Interesting design
c. Easy to do
d. Challenging
e. Group work
f. Individual task
g. Other:

6. Do you find any difficulty while doing the activities?Yes

7. What difficulty did you haveduring the activities?

8. Do you understand the teacher's instruction while doing the task?
Unclear/Confused
$\begin{array}{lllll}1 & 2 & 3 & 4 & 5\end{array}$

9. Is there anything else that you learned in the process that you would like to share? 